
3 Research Square
Preprints are preliminary reports that have not undergone peer review.
They should not be considered conclusive, used to inform clinical practice,
or referenced by the media as validated information.

\title{
Evidence on mental health policy gaps in South East Asia: A systematic review of South East Asian countries with special focus on Myanmar
}

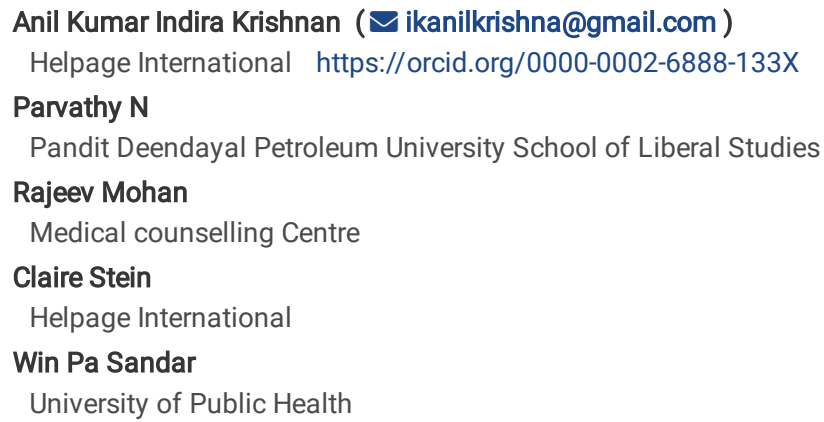

Research article

Keywords: Systematic review, South-east Asia Region, Mental health, Myanmar, national policy, evidence

Posted Date: January 6th, 2020

DOI: https://doi.org/10.21203/rs.2.20080/v1

License: @) (1) This work is licensed under a Creative Commons Attribution 4.0 International License. Read Full License 


\section{Abstract}

Background: The authors synthesised the findings of current and available policies on mental health in the South-East Asian region, primarily focusing and aiming at providing evidence and guidance for framing the mental health policy for Myanmar. Methodology: The research questions were framed using Population, Intervention, Comparison, Outcomes and Study Design (PICOS) framework and Preferred Reporting Items for Systematic Reviews and MetaAnalysis (PRISMA) guidelines were used for study selection. A comprehensive literature search of different electronic databases such as Medline, Science Direct, SCOPUS, Web of Science, EMBASE, Cochrane Library of Systematic Reviews and Google Scholar was carried out in order to identify relevant studies. Results: The main findings indicate that very few countries in the South East Asian region currently have a National Policy on mental health, and those that do have encounter several barriers in rolling out these policies. Little importance and efforts have been made to address mental health disorders, making the burden even more difficult to address. Myanmar is considerably behind other countries in the South East Asian region and is in need for developing a national policy and guidelines targeting mental health disorders. Conclusions: In order to address the mental health burden in the country, increased advocacy and evidence-based policy recommendations for integrating mental health services into national health guidelines and policy plans is necessary. Keywords: Systematic review, South-east Asia Region, Mental health, Myanmar, national policy, evidence

\section{Background}

The global burden of Mental, Neurological, and Substance Use Disorders (MNS) is rapidly increasing. MNS are common, highly disabling, and are associated with significant premature mortality. In 2016 , as much as $15 \%$ of the world's population was affected by mental health disorder and/or substance abuse (Richie $\mathrm{H}$ and Roser $\mathrm{M}, 2018$ ). In addition, according to recent WHO data, mental illness has been estimated to account for $30 \%$ of non-fatal disease burden, and $10 \%$ of overall disease burden, including death and disability (IHME, 2018). The numbers are even higher in low- and middle-income countries. In fact, mental disorders among adults in such countries have been estimated around 78\% (Kohn et.al, 2004). According to WHO "Mental health is the foundation for the well-being and effective functioning of individuals" (WHO, WPR 2002). Mental health is a state of balance within a person and between a person and the environment. Physical, psychological, social, cultural, spiritual and other interrelated factors participate in producing this balance. Mental health affects all components of one's lives. In fact, the inseparable links between mental and physical health have been demonstrated. In addition, the lack of attention to MNS imposes enormous human, social and economic toll across the world. If untreated, MNS undermines health capital, and hence human capital development, since them, unlike many of the high-burden diseases, have an early age of onset and are highly prevalent in the working-age population. It has been estimated that the global economy loses about \$1 trillion every year in productivity due to depression and anxiety. Despite these facts, mental health has been given low priority in most countries particularly in developing countries. The total budget allocated for mental health programs is only $1 \%$ of total health budget in most countries, especially in low income countries (WHO-AIMS, 2016), that is primarily due to inequitable utilization of services (Saxena et.al, 2007b).

In the South-East Asian Region (SEAR) countries vary primarily in terms of standard of life, health care systems, and mental health policies. For instance, Singapore, Malaysia and Brunei perform much better in terms of Human Development Index rating (HDI) (Marmais A et.al, 2011). Myanmar on the other hand, ranks low on the HDI, taking the 132th position. In addition, services for mental health issues are lacking. Mental health services in Myanmar are provided by two psychiatric hospitals, 22 psychiatric wards of general hospitals, and 35 outpatient mental health facilities (WHO, 2015). Human resources allocated in the mental health sector are scarce. It has been estimated that only 0.05 psychologists and 0.04 psychiatrists are available per 100,000 population. Table 1 gives a comparative table of socio-demographic and health indicators for countries in SEAR. In addition, human resources often lack clinical competence to target the mental health burden. For instance, even though primary care physicians can prescribe psychiatric medications and have access to treatment manuals, the majority of them have not received training within the past 5 years (WHO, 2011). For every 100, 000 people, only 0.6 trained Mental Health (MH) workers (e.g. psychiatrists, psychiatric nurses) are available, and only $16 \%$ of these work in outpatient settings, as compared to 125 trained MH worker per 100,000 in the USA and 319 per 100,000 in the UK (WHO, 2015).

Myanmar is one of the South East Asian countries facing an increasing burden of disease in terms of mental health, yet significant gaps remain, as outlined above, and little attention has been given. Myanmar has been severely affected by internal conflicts between ethnic groups and ruling government for decades and is now seeing rapid change in terms of political and social environment. The United Nation describes these ongoing changes as "a complex combination of vulnerability to natural disasters, food and nutrition insecurity, armed conflict, inter-communal tensions, statelessness, displacement, trafficking and migration" (United Nations and Partners, 2016). With this changing political and social environment, population is more vulnerable to stressful situations, and to mental health disorders. The global burden of disease study of 2015 reports that depression and anxiety disorders are among the top 10 contributors to years lived with disability and both have increased over the past decade (IHME, 2015). With this in mind, it seems crucial to increase attention to mental health disorders, and to target efforts for reducing this burden of disease.

\section{Objective}

The objective of this paper is to summarize available evidence on initiatives and implementation of mental health programs in South East Asia and compare them with the existing policy initiatives efforts in Myanmar. In addition, this review aims at comprehending the available evidence on mental health programs in South East Asia, as well as the extent of implementation of mental health policies in Myanmar and gathering evidence on mental health policy gaps in Myanmar.

\section{Methods}


A systematic review was performed to identify evidence on implementation of mental health policies in South East Asia. The study selection follows the Preferred Reporting Items for Systematic Reviews (PICOS framework) (Table 2). This systematic review considers all types of studies such as randomized controlled trials, cluster randomized trials, quasi-randomized controlled trials and other epidemiological and implementation studies.

\section{Search strategy}

A comprehensive literature search of different electronic databases such as Medline, Science Direct, SCOPUS, Web of Science, EMBASE, Cochrane Library of Systematic Reviews and Google Scholar was carried out in order to identify relevant studies. References of all primary selected papers and cross references were also searched for relevant articles.

\section{Study selection}

The selected studies were independently assessed by three reviewers and reported using the PRISMA (Preferred Reporting Items for Systematic Reviews) flow diagram (Fig 1). Valid studies were then assessed for their quality before any retrieval of information. Any disagreements between the reviewers were resolved through discussion. Original full text articles published in English in the selected search engines from June 2000 to June 2017 were included in the review.

\section{Results}

\section{Status of mental health in the SEA-Region}

Some SEA countries have shown better performance in terms of mental health care. The 2016 ASEAN report on mental health analysed the mental health situation in SEA-Region. This report mentions that only five countries in the region - Singapore, Malaysia, Thailand, Indonesia and Laos, have a national mental health policy. These countries are also the ones performing better in the mental health sector. WHO's mental health policy report in 2004 suggests that all countries should have mental health policies and that implementation plans are essential for coordination of services and activities to reduce the burden of mental disorders (WHO, 2004b). The authors reviewed evidence for these countries before moving on to the systematic review results. Table 3 summarizes country wise evidence.

Mental health care in Thailand is managed by the Department of Mental Health, which was established in 1994. The department laid down a mental health policy aimed at promoting mental health care by involving citizens in mental health programmes. While developing the policy the focus was on developing sustainable technology by seeking cooperation both within and outside the Ministry of Public Health (Siriwanarangsan P, et. Al. 2004). Within the Department of Mental Health, the National Mental Health Authority was founded to provide advice to the government on mental health policies and legislation, to set the standard of care, and to develop and transfer mental health technologies to all stakeholders. Community level mental health services are integrated with public health service system throughout the Ministry of Public Health administrative infrastructures, from village to regional levels. The department of mental health in Thailand maintains updated knowledge on developing prevention, and treatment programmes for mental health disorders. Components in policy on mental health include the integration of advocacy, community level participation and monitoring of mental health services. In terms of facilities, Thailand has 18 psychiatric hospitals, distributed to every part of country, and 13 mental health centres that are responsible for implementing mental health policy. Three of the 18 psychiatric hospitals are specifically for children and adolescents. Village health volunteers are trained in primary care units to screen mental health problems, to look after the patient, to monitoring cases in the communities, and to transfer cases to more specialized mental health care facilities when necessary. The department of mental health is allocated 84.5 million USD, which is around $2.4 \%$ of total health budget for 2014 (Bureau of Mental Health Strategy, 2014). The budget allocated for mental health promotion and education is approximately $3 \%$ of the total budget allocated to mental health (table 2 ).

In Indonesia, a mental health policy was formulated in 2001 as part of the general health policy. The mental health law was enacted in 2014 , which helped in developing national and provincial mental health policy plans. The country established a directorate for mental health services and developed mental health community residential facilities for providing mental health care. With the enactment of this law, the policies and programmes for mental health were given priority. Like Thailand, Indonesia also engages community participation for improving mental health situation. The involvement of national and international NGOs also help in providing mental health care for the needy. The mental health care services are evolving positively. The proportion of primary health care units which provide mental health care increased from $13.7 \%$ in 2011 to $20 \%$ in 2012 . WHO data from 2011 showed that around $46.5 \%$ of the staff at the primary level were trained in mental health programs. The main concern in providing mental health care is rotation of trained staff to other facilities where mental health care is not available. The mental health budget calculation for Indonesia is problematic as the fund allocation comes from different departments. The total budget for mental health from the Ministry of Health has been estimated at $2.89 \%$, with more than $90 \%$ of this budget allocated to mental hospitals (ASEAN,2016).

In Malaysia, after the country gained independence from the British in 1957, post graduate training programs in psychiatry and undergraduate departments of psychiatry were initiated, and four mental hospitals were opened. In the country, the development of mental health services is guided by the vision and mission of the Ministry of Health, the National Mental Health Policy, and the National Framework of Mental Health. The National Mental Health Policy was formulated in 1998 and was revised in 2012. Malaysia also stresses the need of community level mental health centres and psychiatric nursing homes, which is emphasised as a main component in Act and Legislation. The mental health care in Malaysia is carried out through three major methods, (i) mental health services in primary health care, (ii) mental health services in hospitals, and (iii) community based mental health services. Community based mental health care has a major role in providing mental health care. Activities include early assessment and treatment; day hospital treatment; supported employment; social skills training; and a family link programmes. There is no budget specifically allocated for mental health programme, as it comes along with the other national health programmes. Nevertheless, estimations for resources used for mental health services ranged from $0.28 \%$ to $0.39 \%$ of the total budget (ASEAN, 2016). 
In the Philippines, a multi-sectoral consultation in the late 1980s led to the National Program for Mental Health at the Department of Health, which was revived in 2002. A mental health policy was signed in 2001, however, implementation was not carried out (Conde B, 2004).

Laos PDR developed mental health policy in 2007, followed by strategy on mental health 2013 , however the strategy was not implemented due to financial and human resources co200nstraints (ASEAN, 2016).

Myanmar on the other hand is one of those countries with no mental health policy. Mental health services in the country are provided both by government, NGOs and community based ethnic groups. NGOs and other organizations are demanding increased role of the government. The National Health Plan (20172021) highlights the human resource issue, calling for an assessment of skills needed at different levels in the health system and for different lines of workers (Ministry of Health and Sports, 2016).

\section{Systematic review}

The authors reviewed available published evidence on mental health environments, and gaps in the health sectors in the SEA-Region, based on the 16 selected papers. Findings are summarized in table 3.

A study conducted by Chong et al (2012) investigated the situation of mental health of adults and types of care in Singapore by using a cross sectional epidemiological methodology. Data on prevalence rates, unmet needs, disabilities and service used for mental disorders was provided. The study identified gaps in the health care system and identified the need for psychiatrists' involvement in supervising, training, monitoring and evaluating the mental health programmes in the country. There is also an increased need for mental health professionals' involvement in policy making. Such information is crucial to assess the impact of mental disorders and to guide the development and delivery of services in the next phase of the national mental health blueprint (Chong et al, 2012).

Nguyen et.al conducted a literature review of published and grey articles on mental health interventions in Myanmar. The study found that "People from Myanmar experience mental health problems due to stress that are similar to those in other populations for whom psychotherapeutic interventions are shown to be effective". While this evidence supports the pertinence of similar services for Burmese people, very little information has been published on the availability or effectiveness of psychosocial and psychotherapeutic interventions in the country. Much of what is available consists only of preliminary evaluations of programs delivered by non-governmental or community-based organizations, with few details on specific programme activities (Nguyen et.al, 2018).

Kelley L et.al did a political economy analysis of the mental health situation in Vietnam to enhance knowledge translation, notably how both explicit and implicit knowledge can be used to promote evidence-based policy making. The paper argues that mental health needs in the country are linked with the transitions that economic globalisation has led to. The article concludes that mental health needs are particularly acute for countries in rapid transition due to globalisation. Transition in Vietnam poses both a potential threat to the care of people with mental health needs, as well as an opportunity to develop mental health services adapted to local context and LMICs more generally (Kelley L et al, 2015).

Stockwell et.al did a retrospective case study to identify key issues in the mental health policy development process in Cambodia. Ten key informants involved in the policy development process were interviewed using a semi structured questionnaire designed to collect qualitative data about the policy formation process, stakeholders and context. The study found that ministry of health should be primarily involved in the development of mental health plans, involving stakeholder groups during plan preparation. The paper contributes to an increased understanding of how mental health policy gets on the public policy agenda and how policy implementation fails or succeeds (Stockwell et.al, 2015).

A recent article of By Quoi 2018 looks at the overall mental health situation in Myanmar and explains that the country is suffering from a hidden mental health epidemic. Years of internal conflict have led to a traumatized society and a multitude of mental health issues. This epidemic is hidden because unlike physical injuries, mental health issues cannot be easily seen. Yet, below the surface, complications and damage done by mental health issues have ramifications not just for individuals but for society as a whole. In addition, the historical role of the psychiatric hospitals paired with the likelihood of prolonged hospitalization if committed, may reduce help-seeking behaviors (Kent, 1996; Way, 1996; Zaw, 1997). Use of informal service networks for mental health care is not well documented, although anecdotal reports suggest that people in distress may receive counselling support in monastic settings and meditation centres (Way, 1996). Most of the documented psychosocial and psychotherapeutic interventions have been provided by various non-governmental and communitybased organizations (Risso-Gill et al. 2014).

\section{Discussion}

The main challenges for development of mental health services are largely due to lack of attention and investment. Where legislation and policies exist, they are, at best, not entirely implemented, and efforts to modernise mental health systems face numerous obstacles. In most of the countries, mental health spending is no more than $2 \%$ of the total health budget, of which $80-90 \%$ goes to mental hospitals. Major barriers in health care systems remain, such as deficiencies in the workforce; low efforts in terms of mental health advocacy; inadequate protection of the rights of people living with mental disorders; little in the way of rehabilitation services or efforts to promote social and economic inclusion; and treatment services concentrated in urban areas.

In South East Asia, some of the best performing countries in terms of mental health were Singapore, Malaysia, and Thailand. These countries all have a welldefined mental health policy or blueprint which makes it easier to implement a uniform plan of action across the country to a large extent. In addition, these

Page $4 / 10$ 
countries all have existing backup of advanced health and social service systems. An additional reason for increased performance in the mental health sector was the ability to initiate and use community-based services to address mental disorders. The main challenges faced in addressing the burden of mental health were in terms of lack of human resources, cross-sectoral coordination, funding incentives for community treatment, and patient advocacy.

On the other hand, many other Asian countries, namely Myanmar, have no defined mental health policy, or little plans to address to address the mental health burden. Many NGOs have started collaborating with other international donors and technical partners to start programs for addressing the mental health programs in the country. These collaborative projects could help in raising awareness in the community for mental health and fill the void in adequate service provision. Major barriers in the development of mental health services in Myanmar include inadequacy of government facilities, lack in infrastructures, supplies, and human resources devoted to the mental health sector, but also lack of funding. In addition, accessibility is a major challenge in rural areas. To overcome this problem, several NGOs have started training their counsellors who can help in providing services for mental trauma or refer patients to higher facilities. Myanmar could use the example of some of its neighbouring countries to develop and guide mental health policy. The first step in addressing the mental health burden will be in terms of developing a national policy and guidelines targeting mental health disorders and ensuring implementation.

Although guidelines are inappropriate for highly diverse regions, some lessons can be learned from this study to assist progress towards community integration. Various economies are at markedly different stages of reform in the provision of the care, services and environment necessary for integration of people with mental illness into the community. While there is a growing trend across the region in policy and plans to shift from hospital-centric treatments to community-based care, integration for people with mental illness remains slow. Overcoming the regional gap to deliver community-based care requires strong mental health policy implementation, sufficient timeframe, consistent efforts and sustainable integration of all health and non-health sectors to meet the diverse needs of people living with mental illness.

More important than funding is the question of how funds are used and applied according to policy goals. Greater emphasis is needed on developing and integrating a range of system resources, especially to build capacity among NGOs, non-health sectors and non-professionals to deliver community mental healthcare. It is obvious that more reliable data on prevalence, best practices and cost-effective treatments are required. There is a critical need across the Asia Pacific region to strengthen information systems and improve evidence and research in mental health; fundamental goals of the WHO Global Comprehensive Mental Health Action Plan (WHO, 2013).

\section{Limitations}

One limitation and finding of this systematic review was the scarcity of available published literature on policies related to mental health in South East Asia. The objective of our study was to present evidence on current policies in place, and to provide some guidance and recommendations for Myanmar's mental health sector based on evidence from other countries. Mental disorders and its causes were not analysed in the review. In addition, we would like to underline that integration of policies depends to a large extent on the cultural acceptance of those living with mental illness. Explanatory models of mental illness and their treatments are often shaped by different cultures in the Asia Pacific region. For instance, family and societal attitudes towards mental illness are heavily influenced by cultural values, and the concept of recovery may have different meanings in Asian contexts. The development of community-based infrastructure, efforts towards anti-stigma education, human rights campaigns and patient advocacy should consider local cultural appropriateness. We underlined the importance for Myanmar to develop a national policy and guidelines on mental health. However, in order to target the mental health burden and implement effective policies, more research is needed on country context and on effectiveness of such policies.

\section{Conclusion}

This systematic review provides evidence on current and existing policies for mental health across ten South East Asian countries and aims at building evidence for Myanmar. Main findings were that very few countries have been carrying on and efficiently implementing policies on mental health. Myanmar is considerably behind other countries in the SEA-Region and there is immediate need for developing a national policy and guidelines targeted at mental health disorders. This study stresses on the need for increased advocacy and evidence-based policy recommendations for integrating mental health services into national health guidelines and policy plans. Lastly, this study also touches on the importance of understanding the diversity of country contexts and needs and adjusting policies and practices based on such national contexts and needs.

\section{Abbreviations}

HDI-Human Development Index rating

MH-Mental Health

MNS -Mental, Neurological, and Substance Use Disorders

PICOS - Population, Intervention, Comparison, Outcomes and Study Design

PRISMA -Preferred Reporting Items for Systematic Reviews and Meta-Analysis

SEAR- South-East Asian Region

\section{Declarations}

\section{Ethics approval and consent to participate}


Not applicable

\section{Consent for publication}

Not applicable

Availability of data and material

Not applicable

\section{Competing interests}

The authors declare that they have no competing interests

\section{Funding :}

European Union, DCI SANTE/2014/342/298,

Project name: Strengthening public health capacity to respond to Myanmar's disease transition project

Implementation agency: HelpAge international.

\section{Authors' contributions}

Review and Conceptualization and writing done by AK and PN, RM and WP helped with the review, CS helped in research.

\section{Acknowledgements}

We acknowledge the support of European Union

\section{References}

ASEAN. 2016. ASEAN mental health systems. ASEAN secretariat, Jakarta.

Bertrand D, Choulamany C.2002. Mental Health Situation Analysis in Lao People's Democratic Republic. Available at: www.who.int/mental_health/policy/en/lao_mnh_sit_analysis.pdf

Burnard P, Haji Abd Rahim HT, Hayes D, Edwards D.2007. A descriptive study of Bruneian student nurses' perceptions of stress. Nurse Educ Today. 27(7):80818. Epub 2007 Mar 26 Chong SA, Abdin E, et al. 2012. A population-based survey of mental disorders in Singapore. Ann Acad Med Singapore. 41(2):4966. Chong SA, Mythily, Deurenberg-Yap M, Verma S, Swartz M. 2008. Performance measures for mental healthcare in Singapore. Ann Acad Med Singapore. 37(9):791-6.

Chong SA, Vaingankar JA, Subrmaniam M. 2012. Policy Implications of The Singapore Mental Health Study. Ann Acad Med Singapore 2012;41:258-63

Chu AH. Et. Al. 2014. Do workplace physical activity interventions improve mental health outcomes? Occup Med (Lond). 64(4):235-45 Chu AHY, van Dam RM, et al. 2018. Self-reported domain-specific and accelerometer -based physical activity and sedentary behaviour in relation to psychological distress among an urban Asian Population. Int J Behav Nutr Phys Act. 15(1):36. Doi: 10.1186/s12966-018-0669-1.

Conde B. Philippines mental health country profile. Int Rev Psychiatry 2004; 16: 159-66.

Do M, Pham NN, Wallick S, Nastasi BK. 2014. Perceptions of mental illness and related stigma among Vietnamese populations: findings from a mixed method study. J Immigr Minor Health. 16(6):1294-8. Doi: 10.1007/s10903-014-0018-7. Ho H, Adanan AM, Omar R. Psychiatric morbidity and socio-occupational dysfunction in residents of a drug rehabilitation centre: challenges of substance misuse management in a Bruneian context. BJPsych Bulletin. 2015 Oct;39(5):213-7. Doi: 10.1192/pb.bp.113.046300

Institute for Health Metrics and Evaluation (IHME). 2018. Findings from the Global Burden of Disease Study 2017. Seattle, WA. Available at: http://www.healthdata.org/sites/default/files/files/policy_report/2019/GBD_2017_Booklet.pdf

Kelley L, et.al. 2015. The Political Economy of Mental Health in Vietnam: Key Lessons for Countries in Transition. Special Research Article on Health Policy. Asia \& the Pacific Policy Studies, vol. 2, no. 2, pp. 266-279. Available at: https://onlinelibrary.wiley.com/doi/epdf/10.1002/app5.74. Accessed on 14 November 2018.

Kohn et.al. 2004. The treatment gap in mental health care. Bulletin of the World Health Organization. November 2004, 82 (11). Available at: https://www.ncbi.nlm.nih.gov/pmc/articles/PMC2623050/pdf/15640922.pdf. Accessed on 1 ${ }^{\text {st }}$ January 2019.

Kumaraswamy N. 2007. Psychotherapy in Brunei Darussalam. J Clinical Psychology. 63(8):735-44. Literature. Global Mental Health (Camb).

Marmais A, et.al. 2011. Mental health in southeast Asia. Commentary, Lancet. 2011. Available at: https://www.thelancet.com/action/showPdf?pii=S0140$6736 \% 2810 \% 2962181-2$. Accessed on $14^{\text {th }}$ October 2018. 
Marthoenis M, et. Al. 2016. Mental health in Aceh-Indonesia: A decade after the devastating tsunami 2004. Asian J Psychiatry. 59-65. doi: 10.1016/j.ajp.2016.01.002

Ministry of Health. Healthy minds, healthy communities' National Mental Health Blueprint Singapore 2007 - 2012. Available at: https://www.imh.com.sg/uploadedFiles/Publications/IMH\%20National\%20Mental\%20Health\%20Blueprint.pdf

$\mathrm{Ng} \mathrm{CH}(1)$, Than PT, La CD, Van Than Q, Van Dieu C. 2011. The national community mental health care project in Vietnam: a review for future guidance. Australas Psychiatry. 19(2):143-50. doi: 10.3109/10398562.2011.563308 Nguyen A.J, et.al. 2018. Mental health interventions in Myanmar: a review of the academic and grey literature. Global Mental Health. 5. Published online 2018 Feb 19. doi: 10.1017/gmh.2017.30. Available at: https://www.ncbi.nlm.nih.gov/pmc/articles/PMC5827419/pdf/S2054425117000309a.pdf. Accessed on 12 ${ }^{\text {th }}$ January 2019. Parameshvara Deva M. 2004 Malaysia mental health country profile. International Review of Psychiatry. 16(1-2):167-76

Ritchie H and Roser M. 2018. Mental Health. Available at: https://ourworldindata.org/mental-health. Accessed on $21^{\text {st }}$ December 2018.

Saxena S, et.al. 2007. Resources for mental health: scarcity, inequity, and inefficiency. Lancet 2007; 370: 878-89. Available at: https://www.thelancet.com/action/showPdf?pii=S0140-6736\%2807\%2961239-2. Accessed on 21 ${ }^{\text {st }}$ December 2018.

Siow Ann Chong, et al. 2012. Policy Implications of the Singapore Mental Health Study. Annals Academy of Medicine. Vol. 41 No. 6

Siriwanarangsan P, et.al. 2004. Thailand mental health country profile. Int Rev Psychiatry 2004; 16: 150-58.

Somasundaram DJ, et al . 1999. Starting mental health services in Cambodia. 48(8):1029-46

Stockwell A, Whiteford H, Townsend C, Stewart D. Mental health policy development: case study of Cambodia. Australas Psychiatry 2005; $13: 190-94$.

UN Development Programme. Human development report 2010: the real wealth of nations, pathways to human development. 2010. http://hdr. undp.org/en/media/HDR_2010_EN_Complete_reprint.pdf (accessed Nov 17, 2010).

UNDP. 2010. Human development report 2010: the real wealth of nations, pathways to human development. 2010. Available at: http://hdr. undp.org/en/media/HDR_2010_EN_Complete_reprint.pdf. Accessed on 13 ${ }^{\text {th }}$ November 2018.

WHO. 2004a. Global Burden of diseases, 2002: Data sources, methods and results. WHO. Geneva.

WHO. 2004b. Mental health policy, plans and programmes. Geneva, Switzerland: World Health Organization, 2004

WHO. 2006. WHO-AIMS report on mental health system in Myanmar. https://www.who.int/mental_health/evidence/myanmar_who_aims_report.pdf WHO. 2011. Mental Health Atlas 2011 - Indonesia. Department of Mental Health and Substance Abuse, World Health Organization. Available at: https://www.who.int/mental_health/evidence/atlas/profiles/idn_mh_profile.pdf?ua=1\&ua=1

WHO. Mental health atlas 2005. Geneva, Switzerland. 2005. Available at: http://www. who.int/mental_health/evidence/mhatlas05/en/index.html. Accessed on $13^{\text {th }}$ November 2018.

World Health Organization (2013) Comprehensive Mental Health Action Plan 2013-2020. WHO; Available at http://www.who.int/mental_health/action_plan_2013/en/.

\section{Tables}

\section{Table 1 Demographic and health comparison of ASEAN countries}




\begin{tabular}{|c|c|c|c|c|c|c|c|c|c|}
\hline & Brunei & Cambodia & Indonesia & Laos & Malaysia & Myanmar & Philippines & Singapore & $\mathrm{Th}$ \\
\hline Government & Monarchy & $\begin{array}{l}\text { Constitutional } \\
\text { monarchy, } \\
\text { multiparty } \\
\text { democracy }\end{array}$ & $\begin{array}{l}\text { Republic, } \\
\text { multiparty } \\
\text { democracy }\end{array}$ & $\begin{array}{l}\text { Communist } \\
\text { state }\end{array}$ & $\begin{array}{l}\text { Constitutional } \\
\text { monarchy, } \\
\text { multiparty } \\
\text { democracy }\end{array}$ & $\begin{array}{l}\text { Military } \\
\text { regime }\end{array}$ & $\begin{array}{l}\text { Republic, } \\
\text { multiparty } \\
\text { democracy }\end{array}$ & $\begin{array}{l}\text { Republic, } \\
\text { multiparty } \\
\text { democracy }\end{array}$ & $\begin{array}{l}\text { Cons } \\
\text { mon } \\
\text { mult } \\
\text { demı }\end{array}$ \\
\hline Population (millions) & $0 \cdot 4$ & $14 \cdot 5$ & 243 & $6 \cdot 4$ & $28 \cdot 3$ & $53 \cdot 4$ & $99 \cdot 9$ & $4 \cdot 7$ & 67 \\
\hline $\begin{array}{l}\text { Life expectancy at birth } \\
\text { (UN, 2010) }\end{array}$ & $77 \cdot 4$ & $62 \cdot 2$ & $71 \cdot 5$ & $65 \cdot 9$ & $74 \cdot 7$ & $62 \cdot 7$ & $72 \cdot 3$ & $80 \cdot 7$ & 69 \\
\hline $\begin{array}{l}\text { GNI per head (US } \$ P P P, \\
2008)(U N, 2010)\end{array}$ & 49915 & 1868 & 3957 & 2321 & 13927 & 1596 & 4002 & 48893 & 80 \\
\hline $\begin{array}{l}\text { HDI (composite Index) } \\
\text { (UN, 2010) }\end{array}$ & $0 \cdot 805$ & $0 \cdot 494$ & $0 \cdot 6$ & $0 \cdot 497$ & $0 \cdot 744$ & $0 \cdot 451$ & 0.638 & $0 \cdot 846$ & $0 \cdot t$ \\
\hline HDI rank(UN, 2010) & 37 & 124 & 108 & 122 & 57 & 132 & 97 & 27 & $\overline{92}$ \\
\hline $\begin{array}{l}\text { Psychiatric beds per } 10 \\
000 \\
\text { population(WHO,2005) }\end{array}$ & $1 \cdot 2$ & 0 & $0 \cdot 4$ & $0 \cdot 07$ & $2 \cdot 7$ & $0 \cdot 23$ & 0.9 & $6 \cdot 1$ & $1 \cdot 4$ \\
\hline $\begin{array}{l}\text { Psychiatrists per } \\
100,000 \\
\text { population(WHO,2005) }\end{array}$ & 1.9 & $0 \cdot 16$ & $0 \cdot 21$ & 0.03 & $0 \cdot 6$ & $0 \cdot 04$ & $0 \cdot 4$ & $2 \cdot 3$ & $0 \cdot \epsilon$ \\
\hline $\begin{array}{l}\text { Psychiatric nurses per } \\
100,000 \\
\text { population(UN, 2006) }\end{array}$ & $0 \cdot 3$ & $0 \cdot 22$ & $0 \cdot 9$ & 0 & $0 \cdot 5$ & $0 \cdot 01$ & $0 \cdot 4$ & $10 \cdot 4$ & $2 \cdot 7$ \\
\hline $\begin{array}{l}\text { Psychologists per } 100 \text {, } \\
000 \text { population (WHO, } \\
2005 \text { ) }\end{array}$ & $0 \cdot 3$ & $0 \cdot 45$ & $0 \cdot 3$ & 0 & 0.05 & 0.05 & 0.9 & 1 & $0 \cdot 2$ \\
\hline $\begin{array}{l}\text { Social workers per } \\
100,000 \\
\text { population(WHO, 2005) }\end{array}$ & 1 & 0.05 & 1.5 & 0 & $0 \cdot 2$ & $0 \cdot 01$ & 16 & 3 & $0 \cdot \epsilon$ \\
\hline
\end{tabular}

$\mathrm{GNI}=$ gross national income. $\mathrm{PPP}=$ purchasing power parity. $\mathrm{HDI}=$ health development index.

Source: Marmais A et.al, 2011

Table 2: Final search terms used with PICOS framework

\begin{tabular}{|l|l|l|}
\hline Population & Intervention/Comparator & Outcome \\
\hline $\begin{array}{l}\text { Adults population with mental health problem } \\
\text { in South East Asian countries }\end{array}$ & $\begin{array}{l}\text { Policies and interventions targeting control } \\
\text { of mental health problems }\end{array}$ & $\begin{array}{l}\text { Major policies and interventions for } \\
\text { mental health problems } \\
\text { Major implementation gaps in mental } \\
\text { health policy in Myanmar }\end{array}$ \\
\hline
\end{tabular}

Table 3 Country wise evidence on existing mental health policies 


\begin{tabular}{|c|c|c|c|c|c|}
\hline Country & $\begin{array}{l}\text { Policy } \\
\text { available }\end{array}$ & Policy framework & Guiding principles & Challenges & Financing \\
\hline Brunei & No & $\begin{array}{l}\text { No specific policy } \\
\text { only mental health } \\
\text { legislation was } \\
\text { implemented in } \\
2014 .\end{array}$ & $\begin{array}{l}\text { Salient features of mental health } \\
\text { legislation include: } \\
\text { 1. Preservation of individual autonomy } \\
\text { 2. Protecting the best interests of } \\
\text { patients by adapting least restrictive } \\
\text { alternative for treatment, reciprocity } \\
\text { and beneficence, promoting equality } \\
\text { and non-discrimination, and } \\
\text { ensuring multi-agency management }\end{array}$ & $\begin{array}{l}\text { Lack of human } \\
\text { resources and } \\
\text { sustainability of } \\
\text { service }\end{array}$ & $\begin{array}{l}\text { No separate mental health } \\
\text { budget. Funding for } \\
\text { mental health services } \\
\text { comes from the central } \\
\text { hospital budget. }\end{array}$ \\
\hline Cambodia & No & $\begin{array}{l}\text { No specific mental } \\
\text { health policy : the } \\
\text { main features of a } \\
\text { mental health } \\
\text { policy have been } \\
\text { included in the } \\
\text { Mental Health and } \\
\text { Substance Misuse } \\
\text { Plan 2011-2015 }\end{array}$ & $\begin{array}{l}\text { Universal Access to ensure mental } \\
\text { health and substance abuse services }\end{array}$ & $\begin{array}{l}\text { No government } \\
\text { budget for } \\
\text { programs, } \\
\text { funding available } \\
\text { only for staff } \\
\text { salary and some } \\
\text { essential } \\
\text { psychotropic } \\
\text { drugs. }\end{array}$ & $\begin{array}{l}\text { Budget for mental health } \\
\text { in Cambodia is less than } \\
1 \% \text { of the total annual } \\
\text { health budget }\end{array}$ \\
\hline Indonesia & Yes & $\begin{array}{l}\text { First Southeast } \\
\text { Asian country to } \\
\text { pass a specific } \\
\text { Mental Health } \\
\text { Law (1962). } \\
\text { Mental health } \\
\text { policy was enacted } \\
\text { in 1992, and } \\
\text { Mental Health } \\
\text { Law in 2014. }\end{array}$ & $\begin{array}{l}\text { The integration of mental health into the } \\
\text { general health system }\end{array}$ & $\begin{array}{l}\text { Budgeting is } \\
\text { challenging as the } \\
\text { activities are } \\
\text { coordinated by } \\
\text { different } \\
\text { departments }\end{array}$ & $\begin{array}{l}\text { The total budget for } \\
\text { mental health is estimated } \\
\text { to be } 2.9 \% \text { of the Ministry } \\
\text { of Health's budget, of } \\
\text { which more than } 90 \% \text { is } \\
\text { for mental hospitals }\end{array}$ \\
\hline Laos & Yes & $\begin{array}{l}\text { Mental health } \\
\text { policy was made } \\
\text { available in } 2007 \\
\text { as well on the } \\
\text { strategy on Mental } \\
\text { Health } 2013\end{array}$ & -Missing & $\begin{array}{l}\text { No integration of } \\
\text { mental health } \\
\text { policy into health } \\
\text { care system } \\
\text { policy and/or } \\
\text { regulation reason } \\
\text { being lack of } \\
\text { human resource } \\
\text { and financial } \\
\text { constraints }\end{array}$ & $\begin{array}{l}\text { There is limited } \\
\text { government budget to } \\
\text { allocate for mental health } \\
\text { care services }\end{array}$ \\
\hline Malaysia & Yes & $\begin{array}{l}\text { Mental Health } \\
\text { Policy was } \\
\text { formulated in } 1998 \\
\text { and revised in } \\
2012\end{array}$ & $\begin{array}{l}\text { Policy developed on providing universal } \\
\text { access and coverage of mental health } \\
\text { services. }\end{array}$ & - Missing & $\begin{array}{l}\text { Mental Health Financing } \\
\text { Total expenditure on } \\
\text { health (public and private) } \\
\text { in } 2013 \text { was RM35.4 (in } \\
\text { million), } 4.5 \% \text { of GDP. The } \\
\text { mental health budget } \\
\text { accounts for } \\
\text { approximately } 0.28 \% \text { to } \\
0.39 \% \text { of the total health } \\
\text { budget }\end{array}$ \\
\hline Myanmar & No & $\begin{array}{l}\text { No specific policy, } \\
\text { policies related to } \\
\text { mental health are } \\
\text { included in the } \\
\text { National Health } \\
\text { Plan }\end{array}$ & $\begin{array}{l}\text { Provision of mental health services for } \\
\text { prevention of mental health disorders, } \\
\text { strengthening access to mental health } \\
\text { services for all }\end{array}$ & $\begin{array}{l}\text { Stigma attached } \\
\text { with mental } \\
\text { illness } \\
\text { lack of knowledge } \\
\text { about mental } \\
\text { problems by } \\
\text { potential service } \\
\text { users, shortage of } \\
\text { trained personnel }\end{array}$ & $\begin{array}{l}\text { Budget accounts for } \\
\text { approximately } 0.3 \% \text { of the } \\
\text { total health budget }\end{array}$ \\
\hline Philippines & No & $\begin{array}{l}\text { Proposed mental } \\
\text { health bill is } \\
\text { currently under } \\
\text { review by the } \\
\text { Lower House of } \\
\text { Representatives }\end{array}$ & 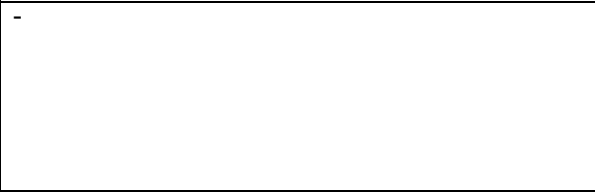 & $\begin{array}{l}\text { Lack of trained } \\
\text { human resource } \\
\text { is a major } \\
\text { challenge }\end{array}$ & $\begin{array}{l}\text { Government has allotted } 5 \\
\text { percent of its total health } \\
\text { budget for mental health. } \\
\text { Most of the budget goes to } \\
\text { operations, mental } \\
\text { hospitals and salaries. }\end{array}$ \\
\hline Singapore & Yes & $\begin{array}{l}\text { Mental health blue } \\
\text { print was } \\
\text { prepared in } 2014\end{array}$ & $\begin{array}{l}\text { Targeted mental health policy guidelines } \\
\text { to cater the needs of different age } \\
\text { groups. Guidelines for different care } \\
\text { agencies who provide mental health } \\
\text { services for the population, including } \\
\text { mental health education, prevention, } \\
\text { early detection and treatment for at-risk } \\
\text { individuals, families and society. }\end{array}$ & $\begin{array}{l}\text { Community } \\
\text { acceptance of } \\
\text { people with } \\
\text { mental illness. } \\
\text { Stigmatisation of } \\
\text { individuals with } \\
\text { mental illness is } \\
\text { an essential } \\
\text { challenge to } \\
\text { overcome }\end{array}$ & $\begin{array}{l}\text { Mental health expenditure } \\
\text { by the government health } \\
\text { department/Ministry } \\
\text { consumes } 4.14 \% \text { of the } \\
\text { total public health budget. }\end{array}$ \\
\hline
\end{tabular}




\begin{tabular}{|c|c|c|c|c|c|}
\hline Country & $\begin{array}{l}\text { Policy } \\
\text { available }\end{array}$ & Policy framework & Guiding principles & Challenges & Financing \\
\hline Thailand & Yes & $\begin{array}{l}\text { Latest plan was of } \\
2005\end{array}$ & $\begin{array}{l}\text { Human resources, involvement of users } \\
\text { and families, advocacy and promotion, } \\
\text { equity of access to mental health } \\
\text { services across different groups, } \\
\text { financing and monitoring system. The } \\
\text { main policy mechanism to improve the } \\
\text { quality of mental health services is } \\
\text { working through the WHO Mental } \\
\text { Health Gap Action Program }\end{array}$ & $\begin{array}{l}\text { Community } \\
\text { acceptance of } \\
\text { people with } \\
\text { mental illness. } \\
\text { Stigmatisation of } \\
\text { individuals with } \\
\text { mental illness is } \\
\text { an essential } \\
\text { challenge to } \\
\text { overcome }\end{array}$ & $\begin{array}{l}\text { The Bureau of Mental } \\
\text { Health Strategy ( } 2014 \text { ) } \\
\text { reported that the total } \\
\text { national health budget was } \\
\text { USD } 76.6 \text { billion US } \\
\text { dollars in } 2014 \text {, } \\
\text { approximately } 4.1 \% \text { of } \\
\text { GDP. }\end{array}$ \\
\hline Vietnam & No & $\begin{array}{l}\text { Many policies that } \\
\text { directly address } \\
\text { mental health or } \\
\text { that are relevant } \\
\text { to mental health } \\
\text { have been issued. }\end{array}$ & $\begin{array}{l}\text { Education communication, expansion of } \\
\text { the mental health facility network, and } \\
\text { training of both mental health care staff } \\
\text { and primary health care staff }\end{array}$ & $\begin{array}{l}\text { Adoption of the } \\
\text { new mental } \\
\text { health policy is at } \\
\text { utmost priority }\end{array}$ & $\begin{array}{l}\text { Most of the funding is } \\
\text { coming from the central } \\
\text { government, but are } \\
\text { specific to different } \\
\text { projects for mental health }\end{array}$ \\
\hline
\end{tabular}

Source: ASEAN, 2016

\section{Figures}
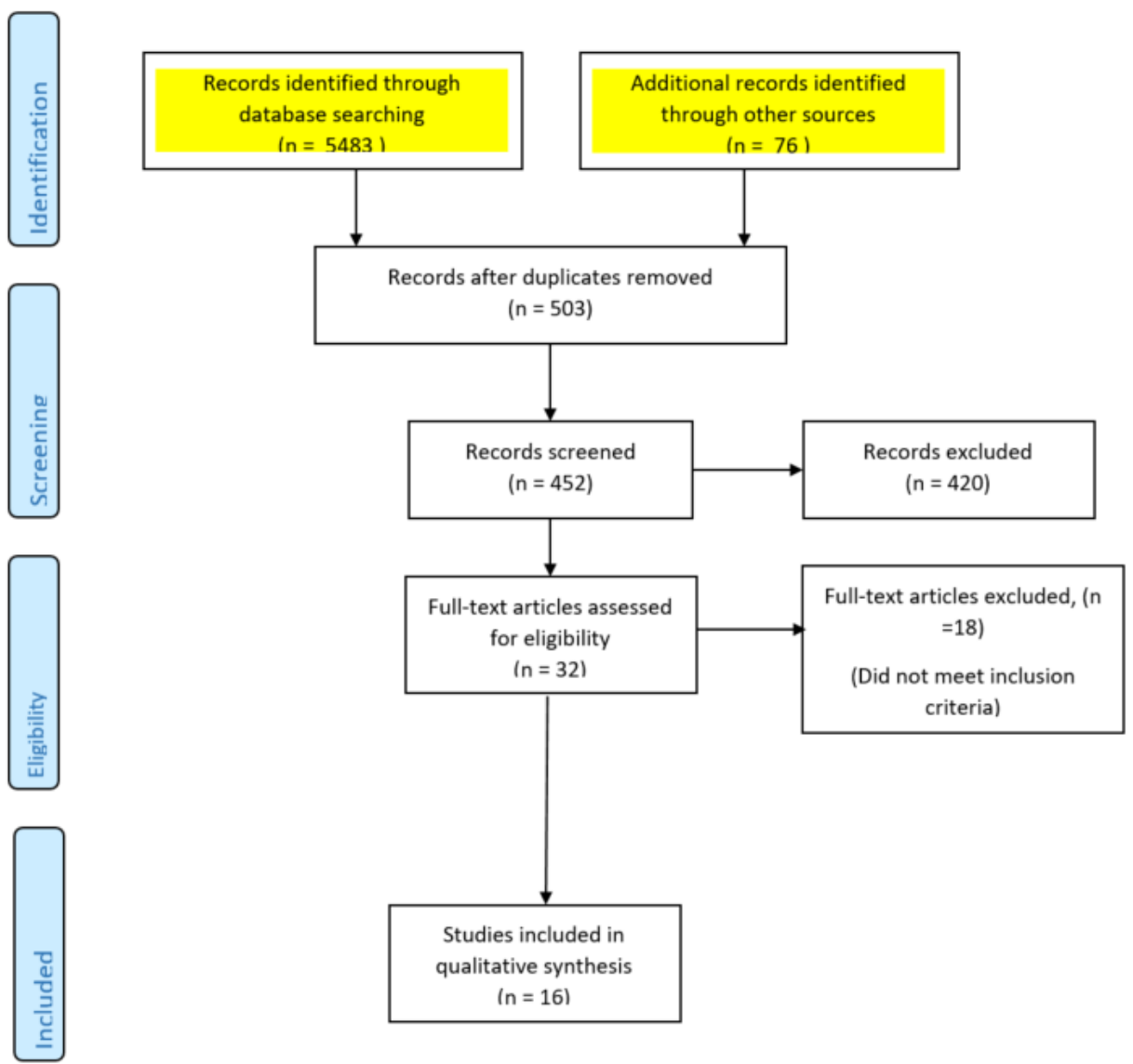

Figure 1

PRISMA Flow Diagram 